\title{
BUDIDAYA TERNAK LEBAH DI DESA SUMBEREJO KECAMATAN MERBAU KABUPATEN DELI SERDANG
}

\author{
Thomson Sebayang ${ }^{1)}$, Salmiah $^{2)}$, Sri Fajar $\mathrm{Ayu}^{3)}$ \\ ${ }^{1,2,3)}$ Fakultas Pertanian, Universitas Sumatera Utara \\ email : thomsonsebayang@yahoo.co.id
}

\begin{abstract}
ABSTRAK
Lebah madu menghasilkan madu yang bersumber dari nektar sewaktu musim tumbuhan berbunga. Lebah mengubah nektar menjadi madu, melalui proses perubahan sukrosamenjadi fruktosa dan glukosa.

Desa Sumberejo adalah desa penghasil komoditi pangan (padi, kedelai, jagung) yang cukup luas. sehingga nektar (pakan lebah) yang akan dihasilkan pun juga akan sangat banyak. Petani Desa Sumberejo selain diuntungkan dari segi penyerbukan secara tidak langsung oleh adanya lebah, petani juga akan memperoleh banyak madu alami. Madu alami dapat dijual secara eceran atau ke perusahaanperusahaan yang membutuhkan bahan baku madu alami. Budidaya lebah madu dapat meningkatkan pendapatan petani.

Budidaya ternak madu merupakan teknologi budidaya sederhana yang mudah dikuasai dan diterima petani serta berbiaya relatif murah sesuai keterbatasan rumah tangga petani. Produk budidaya ini dapat meningkatkan pendapatan dan kesejahteraan petani.
\end{abstract}

\section{ABSTRACT}

Honeybees produce honey derived from nectar during the flowering plant season. The bees turn the nectar into honey, through the process of sucrose to fructose and glucose.

Sumberejo is a village that their people lived from planting paddy, soybean and corn. The area for paddy and other food plant is very wide, almost covered the entire village. This condition is an advantage for people to grow honey bee because it will have a lot of food from the nectar. The honey bee then can be sold as an extra income.

Cultivation of honey is a simple cultivation technology that is easy to be controlled and accepted by farmers. The cost relatively cheap according to the limitations of farm households. This cultivation product can increase farmer's income and prosperity.

\section{PENDAHULUAN}

Madu merupakan cairan kental seperti sirup bewarna cokelat kuning muda sampaicokelat merah yang dikumpulkan dalam indung madu oleh lebah Apis mellifera.Konstituen dari madu adalah campuran dekstrosa dan fruktosa dengan jumlah yang sama dan dikenal sebagai gula invert $50-90 \%$ dari gula yang tidak terinversi dan air.

Madu biasa dipalsukan dengan gula invert buatan, sukrosa, dan glukosa cair perdagangan. Madu dapat pula dipalsukan dengan cara pemberian suatu asupan kepada lebah berupa larutan gula sukrosa yang bukan berasal dari nektar. Madu alami juga banyak mengandung enzim, yaitu molekul protein yang sangat komplek yang dihasilkan oleh sel hidup dan berfungsi sebagai katalisator, yakni : zat pengubah kecepatan reaksi dalam proses kimia yang terjadi di dalam tubuh setiap makhluk hidup.

Lebah madu menghasilkan madu yang dibuat dari nektar sewaktu musim tumbuhan berbunga. Sewaktu nektar dikumpulkan oleh pekerja dari bunga, bahantersebut masih mengandung air tinggi (80\%) dan juga sukrosa tinggi. Setelah lebah mengubah nektar menjadi madu, kandungan air jadi rendah dan sukrosa diubah menjadi fruktosa dan glukosa.

Pakan lebah yang penting adalah nektar yang dihasilkan tanaman. Nektar merupakan hasil sekresi yang manis dari tanaman dan bahan utama penyusun madu. Nektar merupakan senyawa kompleks yang dihasilkan kelenjar nektar tanaman dalam bentuk larutan 
Thomson Sebayang. et al. Budidaya Ternak Lebah Di Desa Sumberejo...

gula. Nektar terdapat pada bagian petal, sepal, stamen dan stigma. Konsentrasi nektar bervariasi antara satu bunga tanaman dengan bunga tanaman lain.

Nektar pada umumnya dihasilkan oleh bunga tanaman pangan, tanaman kehutanan, tanaman perkebunan, tanaman hortikultura (buah dan sayuran), tanaman hias, rumput dan semak belukar. Ketersediaan pakan lebah secara berkesinambungan merupakan salah satu syarat pendukung perkembangan koloni lebah dan produksi madu. Oleh karena itu, faktor pakan penting dipertimbangkan dalam menentukan lokasi budidaya lebah.

\section{METODE PENGABDIAN}

\section{Waktu dan Tempat Kegiatan}

Kegiatan pengabdian dilakukan di Desa

Sumberejo, Kecamatan Merbau, Kabupaten Deli Serdang. Kegiatan demonstrasi pembudidayaan ternak lebah madu ini dilaksanakan pada hari Selasa Tanggal 12 September 2017 bertempat di halaman rumah Ketua Kelompok Tani Harapan Maju, dimana di halaman ini terdapat berbagai tanaman dan pohon buah-buahan sebagai sumber nektar, dan relative sesuai dengan lingkungan pembudidayaan ternak lebah.

\section{Metode Pendekatan}

Pendekatan yang dilakukan dalam mengatasi permasalahan mitra setelah dilakukan identifikasi potensi adalah membuat alternatif rencana kegiatan. Pendekatan yang dilakukan melalui penerapan teknis budidaya praktis yang telah berkembang dimasyarakat melalui media penyuluhan, pelatihan, dan demonstrasi pembuatan produk. Pendekatan tersebut diharapkan dapat meningkatkan pendapatan tambahan bagi mitra dengan mengoptimalkan pemeliharaan ternaknya.

\section{Kegiatan Pengabdian}

$\begin{array}{ccc}\text { Berdasarkan uraian } & \text { prioritas } \\ \text { permasalahan yang } & \text { dikemukakan } & \text { subbab }\end{array}$ permasalahan maka kegiatan yang akan dilakukan meliputi empat aspek pemecahan masalah yaitu dalam hal:

\section{a. Penyuluhan Konsep Beternak Lebah Madu}

Penyuluhan konsep beternak lebah madu akan diberikan penyuluh yang berasal dari Tim Fakultas Pertanian/Program Studi Peternakan USU, sedangkan peserta adalah peternak lebah di Desa Sumberejo. Dalam penyuluhan ini akan diberikan ceramah untuk menjelaskan prinsip beternak lebah yaitu prinsip memilih bibit yang baik untuk dikembangkan, juga dijelaskan keuntungan secara ekonomis pada pembudidayaan lebah tersebut. Ceramah diberikan juga disertai tanya jawab antara peserta dengan penyuluh dari Fakultas Pertanian/Program Studi Peternakan USU. Peternak akan diberi materi yang sederhana dan aplikasi sehingga dapat dengan mudah mereka pahami dan aplikasikan pada ternak lebahnya.

\section{b. Demonstrasi Pembudidayaan Lebah}

Pembuatan

Demontrasi dalam hal ini adalah kegiatan pengenalan akan budidaya ternak lebah kepada peserta, dan selanjutnya dilakukan pelatihan dan demonstrasi pembuatan sarang lebah dari kotak buatan.

\section{c. Demonstrasi Panen dan Pasca Panen Lebah}

Demonstrasi dalam hal ini adalah mempraktekkan langkah-langkah Pengumpulan Madu dari sarangnya, Penyaringan madu dan Pengemasan dalam kemasan botol plastik dan kaca.

\section{d. Partisipasi Mitra}

Mitra yang terlibat dalam demonstrasi pembudidayaan lebah ini adalah pengusaha ternak lebah yang telah berpengalaman relatif lama serta kelompok tani Harapan Maju.

Mewakili mitra pengusaha ternak lebah yang terlibat dalam kegiatan ini adalah Bapak Ginting, sedang mewakili mitra kelompok tani adalah ketua kelompok tani yaitu bapak Cahyadi.

Peran dari mitra pengusaha lebah adalah mendampingi dan memasilitasi tim pelaksana kegiatan dalam penyediaan koloni lebah, pendampingan kelompok tani pada pembuatan wadah pembudidayaan (kotak dan pohon nira) serta membantu memindahkan koloni lebah ke dalam wadah. Sementara itu, peran mitra kelompok tani adalah mengorganisir keiikutsertaan para petani agar dapat mengikuti pembudidayaan lebih ini.

\section{HASIL DAN PEMBAHASAN Kondisi Desa Sumberejo}


Thomson Sebayang. et al. Budidaya Ternak Lebah Di Desa Sumberejo...

Desa Sumberejo adalah desa penghasil komoditi pangan (padi, kedelai, jagung) yang cukup tinggi di Kecamatan Merbau Kabupaten Deli Serdang. Artinya, nektar (pakan lebah) yang akan dihasilkan pun juga akan sangat banyak. Selain petani Desa Sumberejo diuntungkan dari segi penyerbukan secara tidak langsung, petani Desa Sumberejo juga akan memperoleh banyak madu alami. Madu alami tersebut dapat dijual secara eceran dan dapat dijual ke perusahaan-perusahaan yang membutuhkan bahan baku madu alami. Tentunya akan lebih meningkatkan pendapatan warga Desa Sumberejo dari pada warga hanya sekedar menanam tanaman pangan saja.

Desa Sumberejo merupakan salah satu desa di Kecamatan Pagar Merbau Kabupaten Deli Serdang, Provinsi Sumatera Utara. Desa ini mempunyai luas lahan padi dan palawija sebesar $339 \mathrm{Ha}$, ubi kayu sebesar $22 \mathrm{Ha}$, jagun sebesar $10 \mathrm{Ha}$, dan hortikultura sebesar $2 \mathrm{Ha}$. Tanaman- tanaman tersebut tentunya memiliki nektar sebagai pengundang serangga agar membantu tanaman dalam melakukan penyerbukan. Serangga tersebut tidak bermanfaat kepada petani secara ekonomi.

Jika dilakukan budidaya ternak lebah oleh petani, nektar-nektar tersebut akan dihisap oleh lebah petani tersebut dan diolah oleh lebah tersebut menjadi madu alami. Madu alami tersebut dapat dipanen dikandang lebah yang telah petani persiapkan sebelumnya. Setelah dipanen, madu alami tersebut dapat dijual ke pengecer atau ke perusahaan yang membutuhkan bahan baku madu alami. Dapat dikonsumsi sendiri untuk menjaga kesehatan agar tetap prima.

Tanaman pangan (padi, jagung, kedelai) merupakan salah satu penghasil nektar (pakan lebah) yang dapat dimanfaatkan untuk budidaya ternak lebah dan menghasilkan output madu alami dengan nilai jual yang tinggi. Selain dapat dimanfaatkan sebagai pakan ternak lebah, lebah akan melakukan penyerbukan secara tidak langsung terhadap tanaman pangan tersebut sehingga akan menghasilkan output tanaman pangan yang lebih tinggi dari pada sebelumnya.

\section{Kelompok Tani Sasaran}

Kelompok Tani sasaran dari kegiatan pembudidayaan ternak lebah madu ini adalah para petani yang tergabung dalam Kelompok Tani Harapan Maju yang ada di Desa Sumberejo Kecamatan Pagar Merbau
Kabupaten Deli Serdang serta para pemudapemudi yang tergabung dalam organisasi Karang Taruna desa Sumber Rejo. Peserta yang mengikuti kegiatan pembudidayaan ternak lebah di desa ini ada sebanyak 60 orang. Kegiatan demonstrasi pembudidayaan ternak lebah madu ini dilaksanakan pada hari Selasa Tanggal 12 September 2017 bertempat di halaman rumah Ketua Kelompok Tani Harapan Maju, dimana di halaman ini terdapat berbagai tanaman dan pohon buah-buahan sebagai sumber nektar, dan relative sesuai dengan lingkungan pembudidayaan ternak lebah.

\section{Pelaksanaan Kegiatan Pembudidayaan Lenah dan Pengumpulan Madu.}

Kegiatan Pengabdian Masyarakat tentang Pembudidayaan Ternak Lebah Madu ini pada dasarnya dilakukan dalam 2 (dua) tahap, yakni tahap pertama berkenaan dengan Pengenalan dan Pelatihan Teknis Budidaya Lebah dan Pembuatan Demonstrasi Plot Pembudidayaan. Untuk tahap selanjutnya, akan dilakukan beberapa bulan kemudian, setelah lebah berproduksi, dilakukan kegiatan Pelatihan dan Demonstrasi pemanenan lebah dan pengolahan paska panen.

Pada uraian selanjutnya dijelaskan berkenaan dengan kegiatan Pengenalan dan Pelatihan Teknis Budidaya Lebah dan Pembuatan Demonstrasi plot Pembudidayaan Lebah Madu.

\section{a. Pengenalan Budidaya Ternak Lebah.}

Proses pengenalan budidaya ini dijelaskan kepada peserta oleh Tim LPPM-USU didukung oleh mitra, pengrajin ternak lebah dari desa ....kabupaten Karo yang diundang membantu tim sebagai nara sumber, yang telah berpengalaman berpraktek beternak lebah madu sejak tahun 1993.

Produk akhir yang akan dihasilkan melalui proses pembudidayaan lebah adalah lebah madu alami yang dihasilkan oleh lebah lokal jenis Apis melliferamelalui proses pembudidayaan(diternakkan). Madu alami yang dihasilkan, bersumber dari nektar yang dihisap oleh lebah dari bunga tanaman. Saat mencari nektar, lebah juga sebenarnya sedang membantu proses penyerbukan bunga tanaman,dimana hal ini adalah proses penting dalam perkembangbiakan tanaman. Rasa madu yang manis diperoleh dari proses biologis yang 
Thomson Sebayang. et al. Budidaya Ternak Lebah Di Desa Sumberejo...

menghasilkan monosakarida, fruktosa dan glukosa pada madu.

Nektar yang diperoleh lebah pekerja dari bunga tanaman, akan dibawa kembali ke sarangnya. Setelah nektar dikumpulkan, lebah kembali ke sarangnyadan selanjutnya lebah pekerja lain (biasanya lebih muda) mengisap nektar dari perut lebah pekerja yang baru pulang menggunakan proboscis. Lebah pekerja muda yang berada di sarang lantas mengubah nektar menjadi madu.Hal ini dilakukan dengan menambahkan berbagai enzim dari mulut lebah pekerja ke nektar untuk kemudian mengubahnya menjadi madu mentah. Proses ini memakan waktu sekitar 20 menit.

Madu mentah yang dihasilkan selanjutnya disimpan di dalam sarang tempat madu. Pada tahap ini madu masih memiliki kandungan air tinggi.Madu mentah selanjutnya akan secara berangsur berkurang kadar airnya. Kepakan sayap lebah dalam sarang merupakan salah satu cara lebah untuk menurunkan kadar air dalam madu mentah.Madu dianggap matang jika kadar air telah turun ke level tertentu.Madu yang telah matang akan dilindungi dan disimpan dengan bantuan lilin yang dihasilkan oleh semacam lembaran yang ada di bawah perut lebah.Setelah proses ini, madu siap untuk digunakan oleh koloni lebah madu atau dipanen oleh manusia.

\section{b. Pelatihan Teknis Budidaya Lebah}

Setelah dilakukan kegiatan pengenalan akan budidaya ternak lebah kepada peserta, maka selanjutnya dilakukan pelatihan dan demonstrasi pembuatan sarang lebah dari kotak buatan.

Sarang lebah buatan berupa kotak kayu, dibuat menggunakan kayu papan yang kokoh agar tahan lama (sebaiknya dari papan bekas, bukan yang baru), dengan ukuran Tinggi $60 \mathrm{~cm}$, Lebar $30 \mathrm{~cm}$, Tebal (kedalaman) $50 \mathrm{~cm}$. (Sebagaimana diperlihatkan pada Gambar-1).

Didalam kotak dibuat rangka kayu (frame) yang terbuat dari bahan kayu lat, dengan ukuran frame lebih kecil dari ukuran kotak. Dengan demikian, frame dapat masuk dan dipasang di dalam kotak disusun berjajar. Frame ini berfungsi sebagai wadah lebah menggantung untuk membuat sarang. Bagian atas kotak dilapisi seng plat atau di buat atap seng, agar sarang lebah lebih nyaman dan terlindungi dari hujan. Kotak yang telah dibuat, selanjutnya digantung dan ditempatkan disamping batang pohon, menggantung dari permukaan tanah dan diberi penyangga dari broti agar terhindar dari musuh alami yang ada didarat.

Setelah kotak sudah terpasang secara mantap, maka 2 koloni lebah (yang terdiri dari ribuan lebah ratu dan lebah pekerja) dimasukkan kedalamnya. Setiap koloni terdiri dari satu ratu dan lebih dari delapan ribu pekerja. Pembiakan koloni baru berasal dari telur yang dihasilkan oleh ratu disetiap koloni. Pemanenan madu dapat dilakukan setelah 10-15 hari masa tunggu.

Pelaksanaan kegiatan secara ringkas digambarkan dalam flowchart berikut :

Pemahaman proses pembuatan madu alami oleh lebah Apis mellifera

Pengenalan alat dan bahan budidaya lebah Apis mellifera

Praktek pembuatan sarang buatan (kotak lebah)

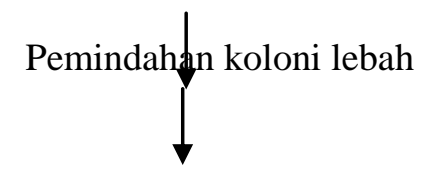

Monitoring hasil pembudidayaan

\section{- Bahan dan alat yang digunakan dalam Budidaya Ternak Lebah Madu.}

Dalam pembuatan kotak sarang lebah, maka bahan dan alat yang digunakan adalah sebagai berikut.

\section{Bahan:}

1. Papan bekas sebagai bahan utama pembuatan kotak lebah.

2. Engsel atau karet ban engsel sebagai alat bantu yang dipasang pada pintu kotak lebah.

3. Seng sebagai penutup/atap kotak lebah.

4. Bambu sebagai sisiran gantungan madu

Alat:

1. Gergaji sebagai alat pemotong papan

2. Paku

3. Martil

4. Cat dan kuas 


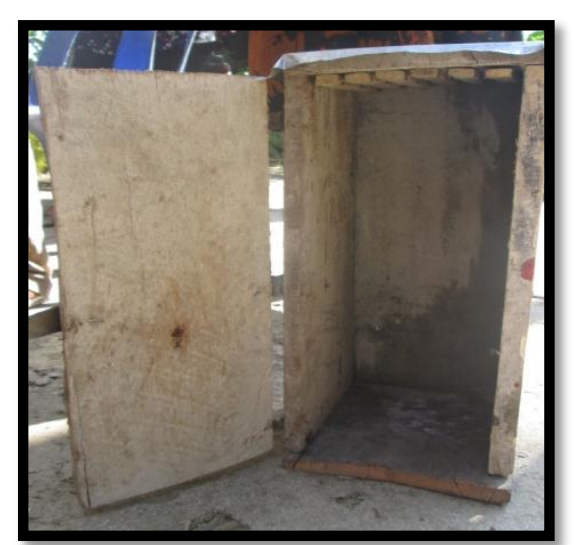

Gambar 1. Kotak Lebah Yang Terbuat Dari Papan Bekas

(Ukuran: Tinggi $60 \mathrm{~cm}$, Lebar $30 \mathrm{~cm}$, Tebal $40 \mathrm{~cm}$ )

\section{- Demonstrasi dan Praktek} Pembuatan Kotak Lebah

Oleh Tim LPPM USU, dilakukan demonstrasi dan praktek pembuatan kotak sarang lebah, dibantu tukang setempat.

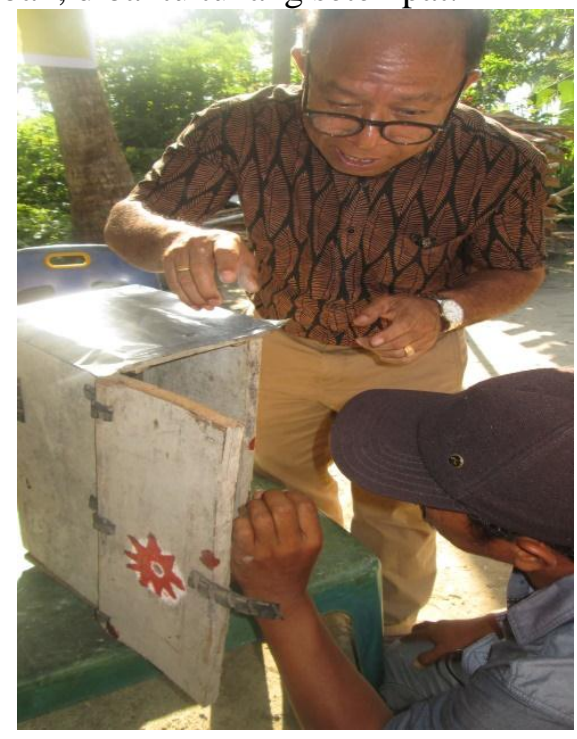

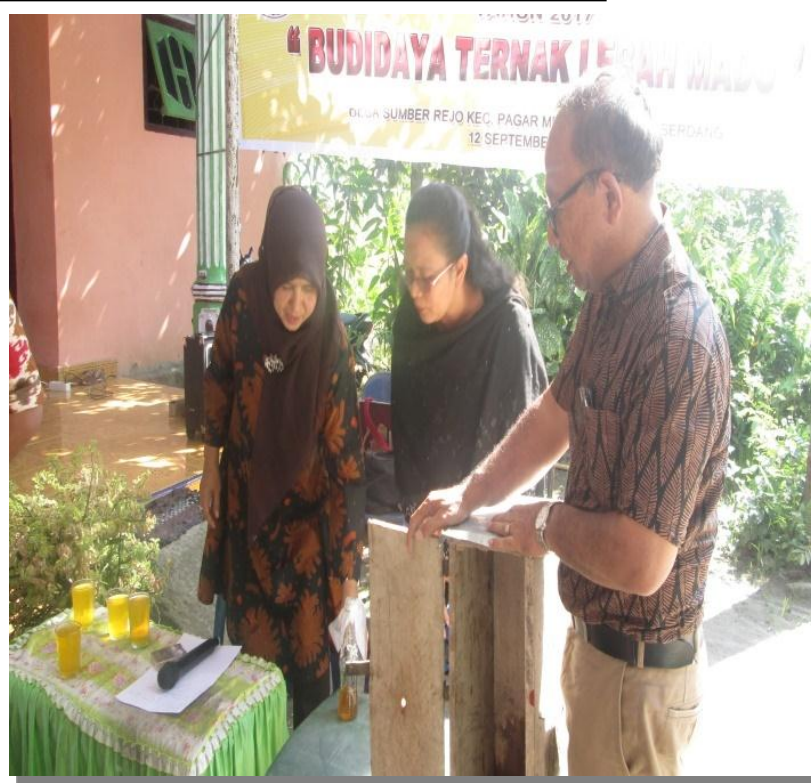

- Proses Pembuatan Kotak Lebah Dari Papan:

1. Lembaran papan dibentuk berbentuk persegi panjang untuk atap, dasar, dinding belakang, dinding depan, dan dinding samping agar terbentuk kotak lebah seperti pada gambar. Tutup bagian depan diberi Engsel agar dapat ditutup dan dibuka.

2. Bagian atas diberi seng sebagai penahan hujan dan panas sinar matahari.

3. Dibuat lubang pada tengah-tengah pintu sebagai jalan keluar masuk lebah.

4. Dibuat gambar bunga dengan warna yang cerah pada lubang seperti warna merah dan kuning sebagai daya tarik lebah untuk masuk kedalam kotak lebah.

5. Dibuat bilah-bilah bambu yang diletakkan di bagian atap dalam kotak lebah sebagai gantungan madu.

6. Dibuat penutup kunci pintu kotak lebah dengan bahan yang sederhana seperti karet ban bekas. 


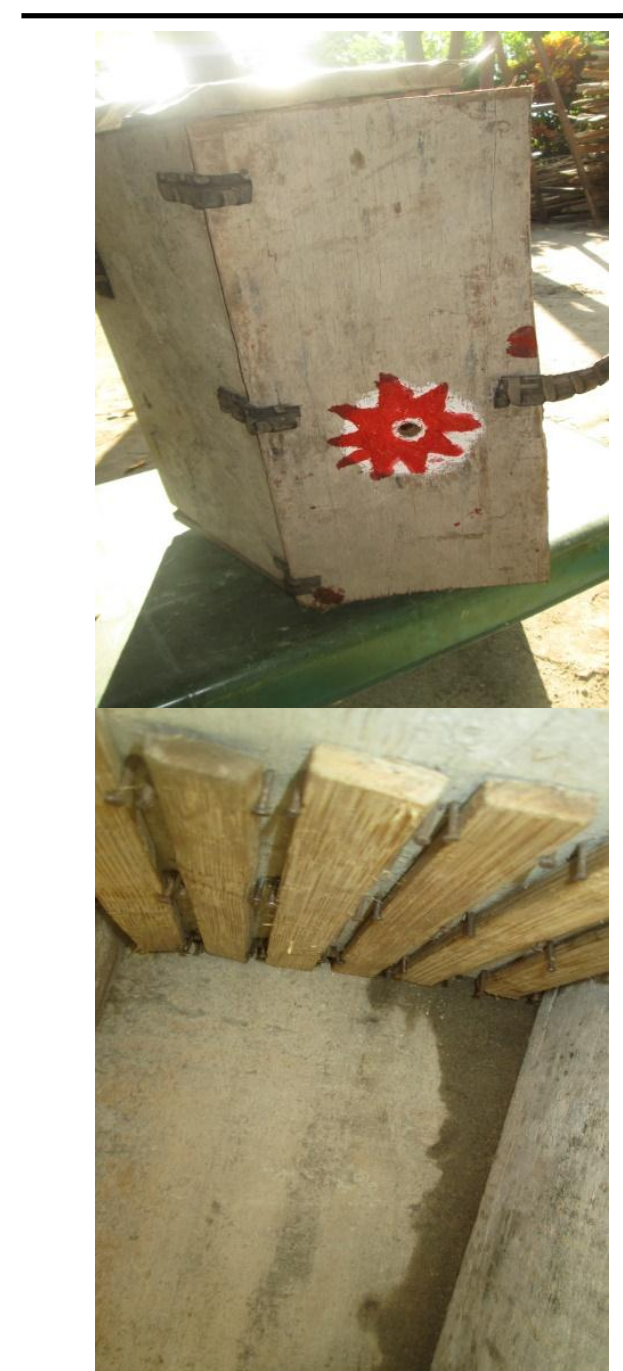

Gambar-2 : Gambar Hasil Akhir Pembuatan Kotak

Sarang lebah ini, selain dibuat dari bahan kayu papan, pada kegiatan ini diberikan juga contoh lain sarang lebah, yang terbuat dari bekas batang nira yang telah dlbersihkan bagian tengahnya. Seperti terlihat pada gambar-3. Panjang batang pohon nira ini sekitar $70 \mathrm{~cm}$.

\section{- Proses Pembuatan Kotak Lebah Dari Pohon Aren.}

Bahan dan Alat yang digunakan dalam pembuatan sarang lenah berbahan batang pohon nira ini adalah sebagai berikut

\section{Bahan:}

1. Potongan pohon aren sebagai bahan utama yang digunakan sebagai sarang lebah.

2. Seng.

3. Potongan papan bekas sebagai pegangan tutup atap.

\section{Alat:}

1. Gergaji sebagai alat pemotong papan

2. Paku

3. Martil

4. Cat dan kuas

\section{Proses Pembuatan Kotak LebahDari Pohon Aren:}

1. Lubangilah ruas pohon aren dari sisi bawah dan atas hingga berbentuk seperti pada gambar.

2. Berilah lubang pada sisi tengah sebagai jalan keluar masuk lebah.

3. Berilah gambar bunga dengan warna yang cerah pada lubang seperti warna merah dan kuning sebagai daya tarik lebah untuk masuk kedalam kotak lebah.

4. Tutup bagian sisi bawah dengan menggunakan papan.

5. Tutup bagian sisi atas menggunakan seng yang telah dibentuk sesuai dengan sisi atap.
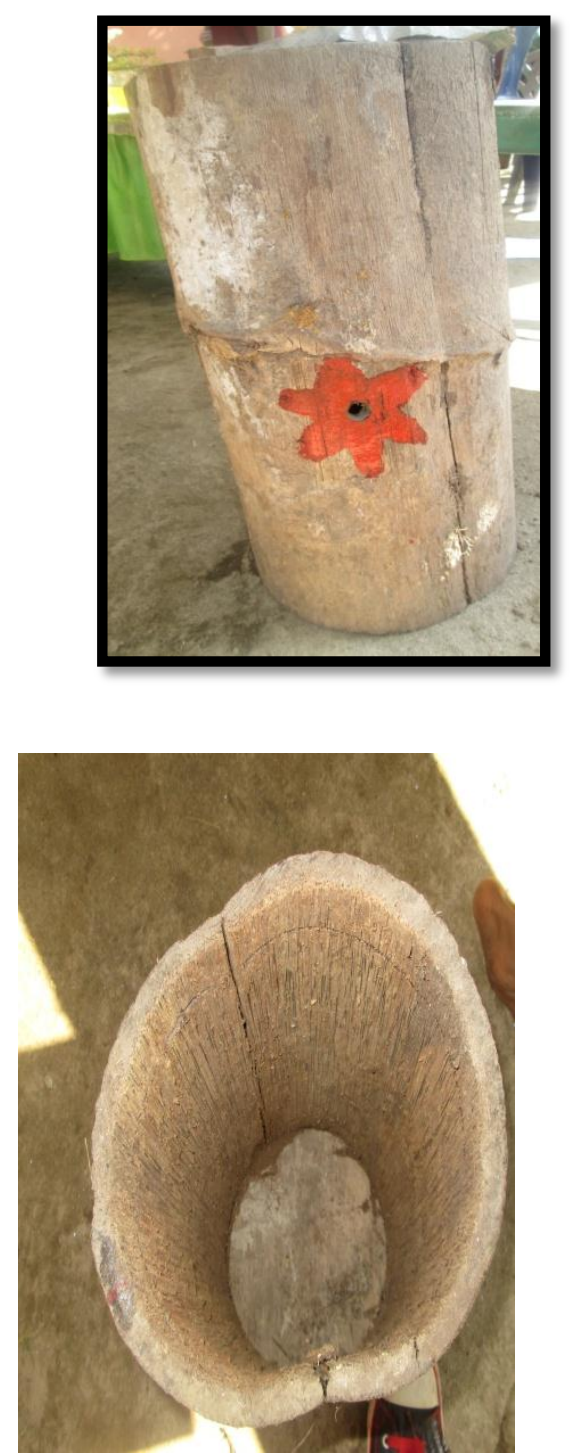

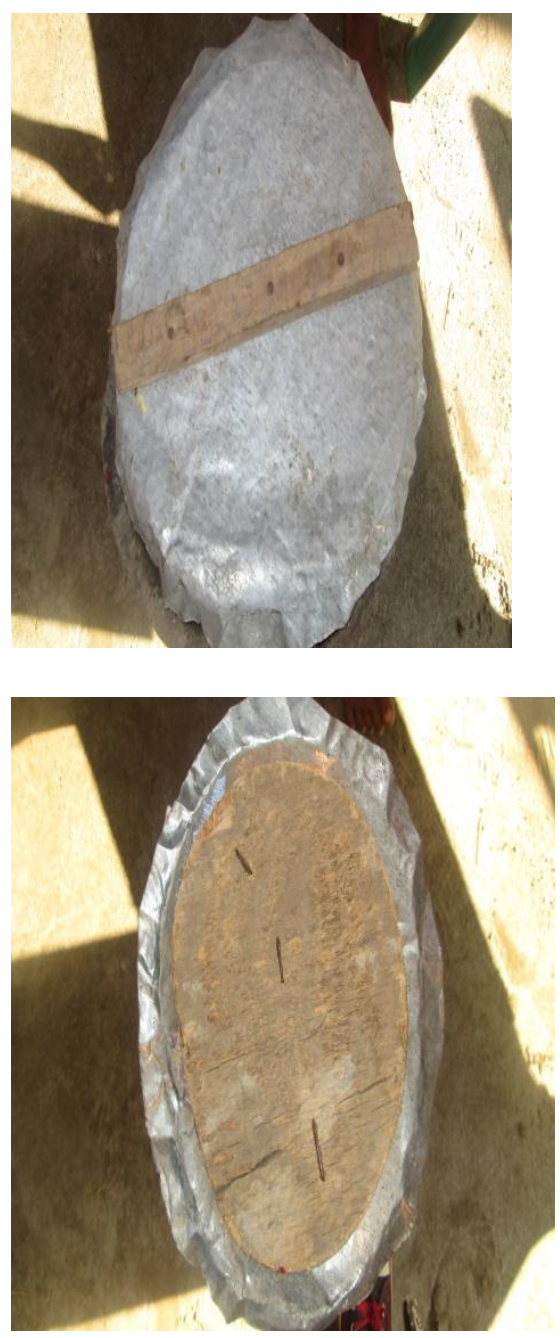

Gambar 3. Kotak Lebah Yang Terbuat Dari Pohon Aren

\section{c. Proses Pemindahan Koloni dan Pembudidayaan Ternak Lebah Madu.}

Setelah wadah pembudidayaan lebah selesai dibuat, baik yang terbuat dari bahan papan/kayu ataupun berbahan pohon aren, maka selanjutnya wadah tersebut digantung (diikat dan dipaku) di sebuah pohon. Tinggi wadah ini dari permukaan tanah berkisar 2 meter.

Setelah wadah telah tergantung secara mantap di atas pohon, maka koloni lebah yang telah tersedia dipindahkan atau dimasukkan kedalam wadah atau kotak. Dalam proses pemidahan ini, seluruh tubuh dan wajah ditutupi kain kelambu dan topi sebagai alat pelindung sengatan lebah.

Sarang lebah yang berisi lebah ratu yang pertama sekali dimasukkan kedalam wadah kotak. Lebah lainnya dalam waktu sekitar satu jam akan beterbangan tidak jauh disekitar wadah. Lebah-lebah ini selanjutnya akan berkumpul menumpuk disekitar kotak dan akhirnya masuk ke dalam sarang mendekati dan diam bersama lebah lebah ratu yang telah ada di dalam wadah. Pada waktunya lebh-lebah ini akan memproduksi madu yang bersumber dari sari bunga tanaman yang ada disekitar lokasi. Panen dilakukan sekitar 2-3 bulan setelah koloni dipindahkan ke dalam wadah.
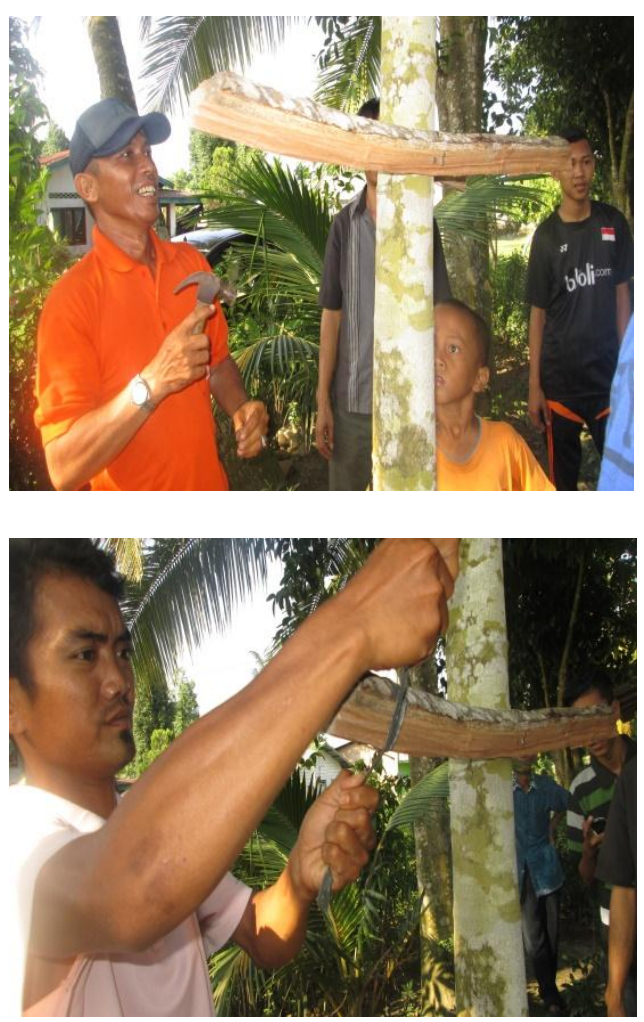

\section{d. DiskusiProses \\ Pemanenan/Pengumpulan Madu}

Panen madu lebah bisa dimulai jika jumlah jumlah lebah dalam satu koloni sarang minimal 25.000 ekor yang memenuhi sisir sarang. Ciriciri madu siap dipanen adalah sisiran telah yang ada telah tertutup oleh lapisan lilin tipis. Sisiran yang akan dipanen dibersihkan dulu dari lebah yang masih menempel, kemudian lapisan penutup sisiran dikupas. Setelah itu sisiran diekstraksi untukdiambil madunya. Ciri sarang siap panen antara lain ukuran sarang memendek atau mengecil, bagian bawah sarang menipis dan keadaan sekitar sarang terlihat bersih.

Proses pemanenan lebah madu dilakukan dengan cara tradisional, dengan cara memanaskan sisiran sarang lebah dengan bantuan air mendidih. 
Thomson Sebayang. et al. Budidaya Ternak Lebah Di Desa Sumberejo...

\section{- Langkah-langkah} madu secara tradisional

Langkah-langkah pengumpulan madu secara tradisional yaitu sebagai berikut :

1. Perlengkapan kerja khusus (kelambu tutup kepala dan topi) dipakai saat memanen lebah madu.

2. Air panas dimasukkan di dalam panci yang berukuran besar, Air panas ini nantinya digunakan untuk memisahkan madu dari sisiran sarang.

3. Kotak lebah madu dibuka dari sisi samping atau belakang lubang keluar masuk lebah madu.

4. Lakukan pengasapan pada kotak lebah madu. Pengasapan ini dilakukan untuk mengalihkan perhatian kumpulan lebah madu dan untuk mempermudah pemanenan.

5. Sisiran sarang yang di penuhi oleh lebah madu diambil dengan bantuan alat pengungkit.

6. Selanjutnya sisiran sarang dibersihkan dari kerumunan lebah madu dengan sikat lebah.

7. Letakkan tempat sisiran yang berisi madu tersebut di tempat yang datar.

8. Potong sisiran sarang lebah madu tersebut dengan pisau. Pemotongan itu dilakukan pada batas antara deretan sarang yang berisi madu .

9. Masukkan potongan tersebut kedalam panci yang berukuran lebih kecil dari panci yang digunakan untuk merebus air.

10. Hasil potongan sisiran sarang yang berisi madu ini siap untuk dipanaskan. Pemanasan ini dilakukan supaya madunya keluar dari sisiran sarang.

11. Setelah air yang ada di panci besar mendidih, masukkan potongan sisiran sarang lebah madu yang berada di panci kecil ke dalam panci besar untuk dipanaskan.

12. Sistem pemanasan ini akan menyebabkan cairan lengket seperti lilin yang menutupi sela-sela sarang madu akan mencair. Kemudian, secara otomatis madunya akan keluar dari sela-sela sarang tersebut.

13. Setelah madunya semua keluar, angkat panci yang berisi potongan sisiran sarang lebah tadi dari kompor, dan biarkan hingga dingin supaya cairan lilin lebah dan madunya terpisah.
14. Madu yang telah terpisah dari lilin lebah ini segera dimasukkan ke dalam botol atau wadah lain, melalui saringan. Hal ini untuk memisahkan madu dari kotoran lainnya.
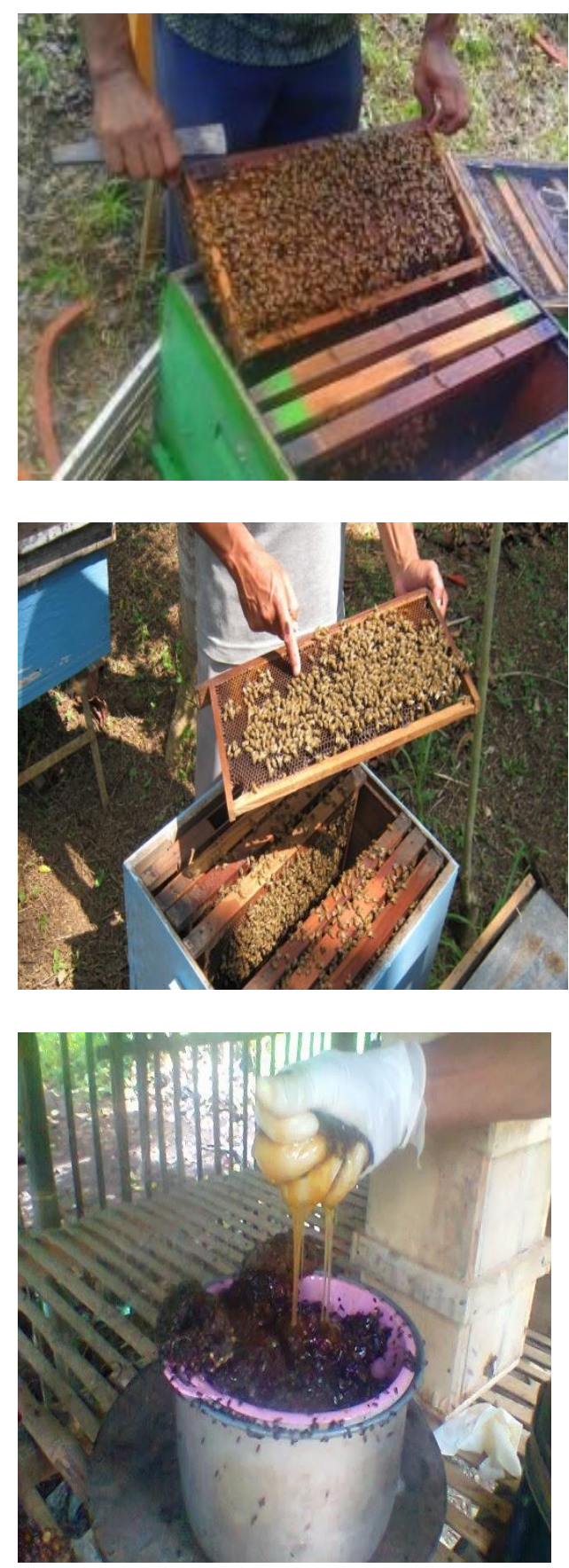
Thomson Sebayang. et al. Budidaya Ternak Lebah Di Desa Sumberejo...

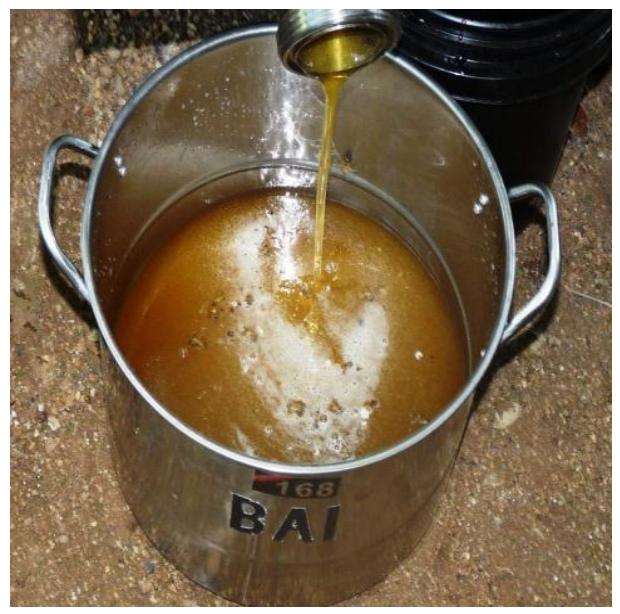

Madu yang dihasilkan oleh lebah madu ada yang berkualitas baik dan ada yang tidak. Beberapa faktor yang dapat mempengaruhi produksi madu dalam sarang antara lain ketersediaan nektar dan serbuk sari, ketersediaan sel telur yang terbuka untuk peletakan, jumlah lebah perawat, dan vitalitas keseluruhan serta kualitas sang ratu.

\section{- Langkah-langkah pengumpulan madu secara Modern}

Teknik pengambilan madu secara modern hanya dapat dilakukan pada sisiran sarang lebah madu yang dilengkapi dengan fondasi sarang. Adapun cara untuk memisahkan madunya, yaitu dengan memutar sisiran sarang lebah tersebut dengan proses ekstraksi menggunakan ekstraktor. Dengan menggunakan alat ini, pemisahan madu dapat dilakukan lebih cepat dan efisien.

Berikut ini langkah-langkah pemanenan madu secara modern :

1. Perlengkapan kerja khusus (kelambu tutup kepala dan topi) dipakai saat memanen lebah madu.

2. Buka kotak lebah dari sisi samping atau belakang lubang keluar masuk lebah madu, sambil sesekali melakukan pengasapan pada kotak madu lebah.

3. Sisiran sarang yang dikerumuni lebah madudiambil dengan bantuan alat pengungkit.

4. Kerumunan lebah madu dari sisiran sarang dibersihkan dengan sikat lebah. Posisi bingkai sisiran sarang pada waktu dibersihkan harus diatas kotak ternak madu.

5. Petakan sisiran yang berisi madu tersebut ditempatkan di tempat yang datar.
6. Lapisan cairan seperti lilin pada sisiran sarang lebah yang menutupi sela-sela sarang yang berisi madu dikupas dengan pisau yang telah dicelupkan dalam air panas terlebih dahulu.

7. Sisiran sarang madu yang telah dikupas lalu dimasukkan ke dalam ekstraktor bersama bingkai atau petakannya. Cara ini untuk memisahkan madu dari sisiran sarang lebah.

8. Alat pemutar ekstraktor dipegang dan diputar secara perlahan-lahan, semakin lama percepat putarannya sampai semua madu mengalir dari sisiran sarang tersebut.

9. Bingkai atau sisiran sarang lebah madu yang telah selesai diproses dengan ekstraktor, sebaiknya jangan dibuang, karena dapat dikembalikan lagi ke dalam kotak lebah seperti semula agar dapat dipergunakan lagi.

10. Setelah semua sisiran sarang diproses dengan ekstraktor, madu yang terkumpul dalam bejana ekstraktor dimasukkan ke jerigen khusus penampungan madu, dengan bantuan gayung sambil dilakukan proses penyaringan.

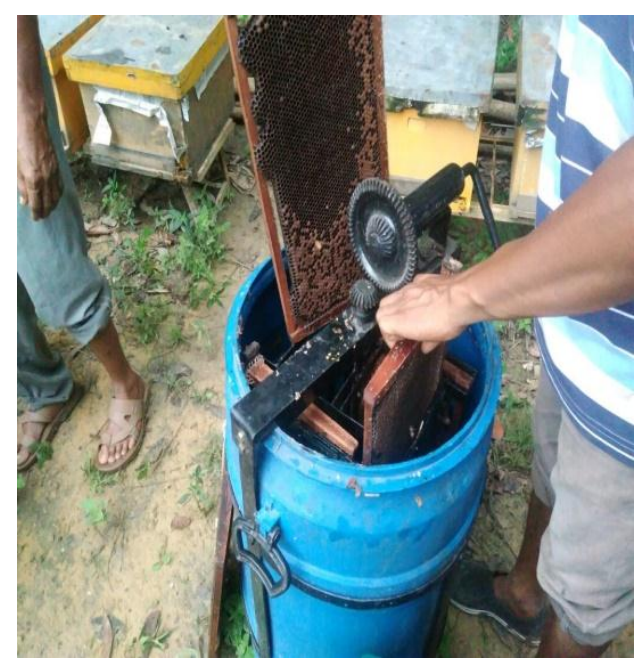




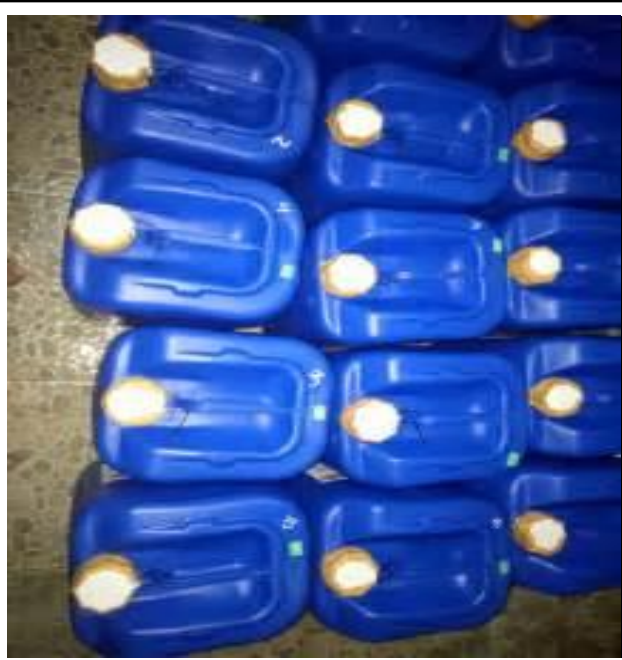

\section{- Pengemasan Madu}

Pengemasan juga berperan dan memiliki efek pada pemasaran produk tersebut, berikut salah satu contoh pengemasan madu mengunakan botol:

1. Hasil madu yang berada di jerigen dituangkan ke dalam botol dengan bantuan corong.

2. Wadah produk madu mengunakan botol, tersedia dalam berbagai ukuran botolsyaitu $650 \mathrm{ml}, 600 \mathrm{ml}, 350 \mathrm{ml}, 250 \mathrm{ml}, 150, \mathrm{ml}$ dll, Hal ini memungkinkan produk madu lebih bervariasi. Menggunakan botol juga dianggap lebih sehat, aman dan transparan.

3. Setiap produk madu yang di dalam botol dapat memiliki label dari instansi kesehatan atau pemerintah setempat .

4. Produk madu lebah alami dalam kemasan botol, siap untuk dipasarkan.

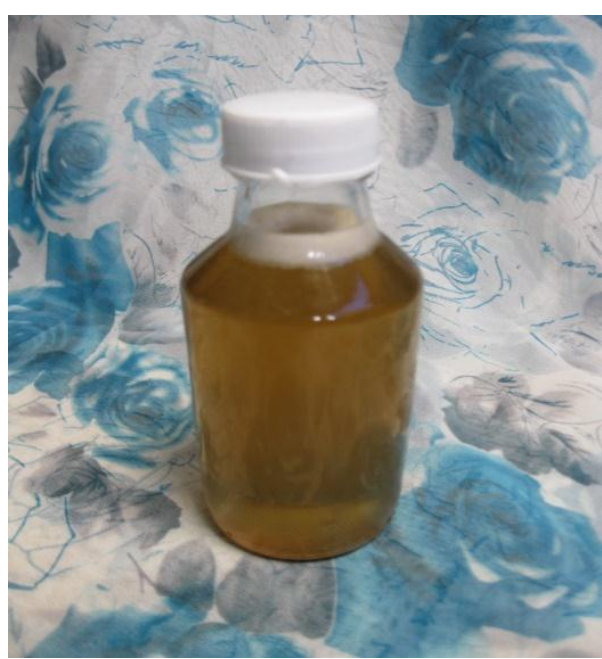

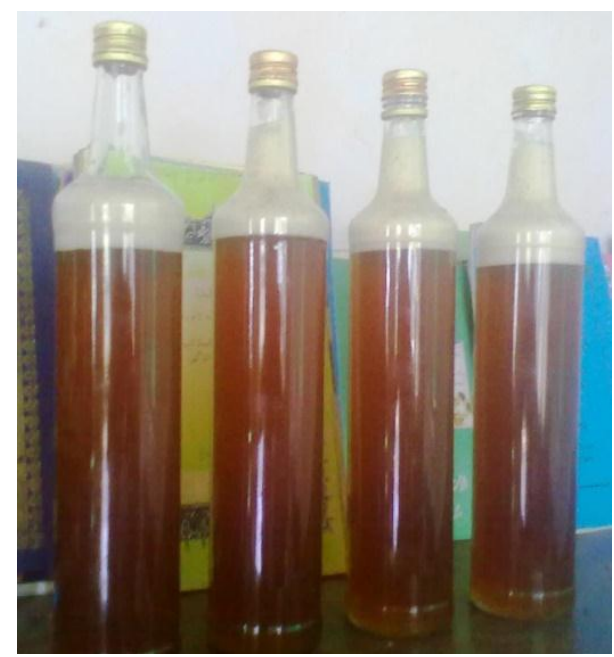

\section{Kualitas madu dapat dilihat dari} beberapa hal berikut ini :

- Madu yang baik adalah madu yang mengandung kadar air sekitar 17-21 persen.

- Biasanya warna madu cenderung akan mengikuti tanaman penghasil nektarnya, misalnya madu yang berasal dari tanaman lobak akan berwarna putih seperti air, madu yang berasal dari tanaman akasia dan apel akan berwarna kuning terang, sedangkan madu yang berasal dari tanaman lime akan berwarna hijau terang.

- Aroma madu ada hubungannya dengan warnanya. Makin gelap warnanya, aromanya makin keras atau tajam.

- Rasa manis madu alami melebihi manisnya gula karena kadar atau tingkat kemanisannya itu sedikitnya bias mencapai 1 1/2 kali dari rasa gula putih/pasir.

- Jika dilakukan uji enzimatis, terdapat dua enzim yang mencolok dalam madu, yaitu enzim diastase dan invertase.

\section{Realisasi Biaya Pelaksanaan}

Biaya yang digunakan dalam melaksanakan kegiatan pembudiayan ternak lebah ini adalah sebesar Rp. 25.000.000 (dua puluh lima juta), yang direalisasikan dalam 2 (dua) tahap yakni tahap pertama 70 persen dan tahap kedua 30 persen. Realisasi penggunaan dana ini, secara rinci diuraikan dalam Lampiran. 


\section{KESIMPULAN}

Budidaya ternak madu merupakan teknologi budidaya sederhana yang mudah dikuasai dan diterima petani serta berbiaya relatif murah sesuai keterbatasan rumah tangga petani. Produk budidaya ini dapat meningkatkan pendapatan dan kesejahteraan petani.

\section{REFERENSI}

Marhiyanto, B., 1999, Peluang Bisnis Beternak Lebah, Gitamedia Press, Surabaya.

Suharno dan Nazaruddin, 1994. Ternak Komersial. Penebar Swadaya. Jakarta

Sumoprastowo, RM, Suprapto Agus, R,. 1993, Beternak Lebah Madu Modern, Bhratara, Jakarta

Trubus 4, 1988, Manisnya Rupiah dari Madu Lebah, Penebar Swadaya, Jakarta 